\title{
Morphoagronomic Characterization of Tomato Plants and Fruit: A Multivariate Approach
}

\author{
Aniela Pilar Campos de Melo, ${ }^{1}$ Paulo Marçal Fernandes, ${ }^{2}$ Fábio Venturoli, ${ }^{3}$ \\ Carlos de Melo Silva-Neto, ${ }^{3}$ and Aurélio Rubio Neto ${ }^{4}$ \\ ${ }^{1}$ Federal University of Goiás, Sector of Horticulture, Brazil \\ ${ }^{2}$ Federal University of Goiás, Sector of Phytosanitary, Brazil \\ ${ }^{3}$ Federal University of Goiás, Sector of Forestry, Brazil \\ ${ }^{4}$ Federal Institute Goiano, Brazil
}

Correspondence should be addressed to Aniela Pilar Campos de Melo; aniela.pcdmelo@gmail.com

Received 12 July 2015; Accepted 15 September 2015

Academic Editor: Gábor Kocsy

Copyright (C) 2015 Aniela Pilar Campos de Melo et al. This is an open access article distributed under the Creative Commons Attribution License, which permits unrestricted use, distribution, and reproduction in any medium, provided the original work is properly cited.

\begin{abstract}
Consumers in the fresh fruit market choose fruits mainly following criteria related to the external appearance. However, the introduction of new material for planting depends on the productive capacity of the plant as well as on the formation of fruit that meets consumer desires. Given the above, the objective of this study was to morphoagronomically characterize tomato genotypes using multivariate statistics. The genotype seedlings (Ellus, Black Mauri, Green Zebra, Green Tomato, Pomodoro Marmande, Pomodoro Fiorentino, Pitanga, and Black Krim) were transplanted 30 days after sowing. The morphoagronomic characterization of the genotypes was carried out by evaluating plants and fruits. The data were analyzed using descriptive analysis, namely, position and variability measurements. In addition, a multivariate cluster analysis and a principal component analysis were carried out for plant and fruit attributes. The cluster and principal component analyses were efficient in characterizing plants and/or fruits of different tomato genotypes. Such efficiency enhances result interpretation and proposed inferences, with applied relevance for the producers. The genotype Ellus has a combination of morphoagronomic plant and fruit traits superior to other genotypes. Such superior traits enable a high productivity.
\end{abstract}

\section{Introduction}

The tomato (Solanum lycopersicon L.) was originated in South America and is the second most important vegetable in economic importance and consumption in the world, second only to potatoes [1]. Bioactive substances such as carotenoids (lycopene, $\beta$-carotene, and lutein), phenolics (flavonoids, phenolic acid, and tannins), and vitamins (C, E, and B) $[2,3]$ are obtained by the in natura consumption of fruits. These compounds positively affect health for having anti-inflammatory and anticancer effects and preventing chronic diseases (obesity, diabetes, coronary heart disease, and hypertension) [4-7].

Consumers in the fresh fruit market choose fruits mainly following criteria related to the external appearance [8].
Color, size, shape, and texture are the first attributes evaluated. Therefore, the introduction of new material for planting depends on the productive capacity of the plant as well as on the formation of fruit that meets consumer desires [9].

In general, the phytotechnical characterization of plants and fruits of different tomato genotypes is carried out by tests that distinguish the phytotechnical characteristics using only analysis of variance and mean comparison tests. Studies on the existing relationship among phytotechnical characteristics, among genotypes, and within genotypes are deficient in the scientific literature. Therefore, the proposed inferences are somewhat superficial.

An approach appropriate for a thorough study on such relationships is the use of multivariate techniques [10]. All variables are simultaneously assessed by exploratory or 
TABLE 1: Height 35 DAT ( $H$-35), number of flowers 35 DAT (FLO-35), number of fruits 35 DAT (FRU-35), number of fruits 80 DAT (FRU-80), estimated production (EST-PRO), estimated productivity (EST-PROD), and growth habit (GHAB) of tomato genotypes.

\begin{tabular}{lcccccrr}
\hline Genotypes & $\begin{array}{c}H-35 \\
\mathrm{~cm}\end{array}$ & $\begin{array}{c}\text { FLO-35 } \\
\text { Plant }\end{array}$ & $\begin{array}{c}\text { FRU-35 } \\
\text { Plant }\end{array}$ & $\begin{array}{c}\text { FRU-80 } \\
\text { Plant }\end{array}$ & $\begin{array}{c}\text { EST-PRO } \\
\text { kg plant }^{-1}\end{array}$ & $\begin{array}{c}\text { EST-PROD } \\
\text { ton ha }^{-1}\end{array}$ \\
\hline Ellus & 180.75 & 11.00 & 11.00 & 39.50 & 3.77 & 62.95 & Undetermined \\
Black Mauri & 175.87 & 11.87 & 12.62 & 79.00 & 1.38 & 23.04 & Undetermined \\
Green Zebra & 118.00 & 5.75 & 2.12 & 27.12 & 1.42 & 23.73 & Undetermined \\
Green Tomato & 168.12 & 11.25 & 9.50 & 24.62 & 1.47 & 24.53 & Undetermined \\
Pitanga & 142.25 & 13.50 & 4.12 & 20.87 & 1.63 & 27.25 & Undetermined \\
Black Krim & 79.50 & 31.00 & 13.25 & 19.87 & 1.37 & 22.84 & Determined \\
Pomodoro Fiorentino & 117.75 & 12.87 & 4.00 & 23.50 & 1.69 & 28.25 & Undetermined \\
Pomodoro Marmande & 103.50 & 10.37 & 5.87 & 13.87 & 1.27 & -21.29 & Undetermined \\
\hline CV (\%) & 5.94 & 24.26 & 64.90 & 19.22 & - & - & - \\
\hline
\end{tabular}

CV: coefficient of variation.

inference techniques that enable checking possible links, similarities, or differences among variables [11]. Therefore, the interpretation of data structure is optimized, mainly providing a reduction in information and time loss.

Given the above, the objective of this study was to morphoagronomically characterize tomato genotypes using multivariate statistics (exploratory techniques such as cluster analysis and principal component analysis).

\section{Material and Methods}

The study was carried out in a greenhouse present in organic system ( $16^{\circ} 57^{\prime} 51.79^{\prime \prime} \mathrm{S} ; 49^{\circ} 11^{\prime} 02.09^{\prime \prime} \mathrm{O}$; $865 \mathrm{~m}$ altitude). The soil is classified as Red Oxisol and has the following physical and chemical attributes: texture (clay 26\%, silt $7 \%$, and sand $67 \%), \mathrm{pH}$ (6.3), organic matter (27\%), cation exchange capacity (CEC) (7.5), base saturation (81.36\%), K (214 ppm), and $\mathrm{Ca}(4.0 \mathrm{mE} / 100 \mathrm{~mL})$.

The genotype seedlings (Ellus, Black Mauri, Green Zebra, Green Tomato, Pomodoro Marmande, Pomodoro Fiorentino, Pitanga, and Black Krim) were transplanted 30 days after sowing. The plantation was fertilized applying a kilogram of poultry manure $\left(26.4 \mathrm{~g} \mathrm{Kg}^{-1}\right.$ of nitrogen, $84.0 \mathrm{~g} \mathrm{Kg}^{-1}$ of $\mathrm{P}_{2} \mathrm{O}_{5}, 23.0 \mathrm{~g} \mathrm{Kg}^{-1}$ of $\mathrm{K}_{2} \mathrm{O}, 112 \mathrm{~g} \mathrm{Kg}^{-1}$ of $\mathrm{Ca}, 6.4 \mathrm{~g} \mathrm{Kg}^{-1}$ of $\mathrm{Mg}$, $2.5 \mathrm{~g} \mathrm{Kg}^{-1}$ of $\mathrm{S}$, and a $7.25 \mathrm{pH}$ ) per meter. The lines were separated by a distance of 1 meter and the plants by 0.6 meters. The tomato support system consisted of a double rod with a narrow ribbon. The removal of excess shoots was held weekly as of 30 days after transplanting (DAT).

The morphoagronomic characterization of the genotypes was carried out by evaluating plants and fruits. The growth habit, shoot height, number of flowers, and number of fruits were determined in eight plants of each genotype, randomly picked, at 35 DAT.

At 80 DAT, 24 fruits were harvested from eight plants of each genotype and the following measures were obtained: fresh mass weight (gravimetry), longitudinal diameter (direct measurement with calipers), transversal diameter (direct measurement with calipers), epicarp, mesocarp, and endocarp coloring (visual method), number of locules, mesocarp thickness (direct measurement with calipers), epicarp firmness (texturometry), and seed quantity per fruit. The number of fruits per plant was again counted 80 DAT to estimate the yield per plant (number of fruits $*$ fruit mass) and production in tons per hectare (yield per plant $* 16666 / 1000$ ).

The data were analyzed using descriptive analysis, namely, position (mean) and variability (coefficient of variation) measurements. In addition, a multivariate cluster analysis and a principal component analysis (PCA using correlation matrices) were carried out for plant and fruit attributes. The cluster dendrogram was obtained through the UPGMA (Unweighted Pair Group Method using Arithmetic Averages), using the Euclidean distance as a similarity coefficient.

\section{Results and Discussion}

A large variation in the number of fruits per plant (35 DAT), number of locules, and firmness was observed among the evaluated genotypes (coefficient of variation of $64.90 \%$, $37.40 \%$, and 28.73\%, resp.; Tables 1 and 2). Tables 1 and 2 exhibit parameters associated with height and flowers and fruits production of the tomato genotypes evaluated. Height, flower production, and fruit production had a high variability and thus may be used as indicating variables for material selection in genetic improvement programs [1].

The genotype Ellus stood out among the others for having a higher estimated fruit production per plant and area (Table 1) and for the fruit traits related to mesocarp mass and thickness (Table 2). The genotype Black Krim had the highest number of flowers, but it did not result in the greatest fixing and fruit formation. Some genotypes or/and cultivars are more sensible to abiotic factors in the reproductive phase, such as temperature and radiation $[12,13]$. High temperatures cause flowers to fall, affect pollen viability and/or fertilization, and lead to a low fruit set.

The genotypes Ellus, Black Mauri, Pitanga, Black Krim, Pomodoro Fiorentino, and Pomodoro Marmande had fruit with a reddish epicarp, with tonal variations (Table 3). Specifically, materials for industrial processing (e.g., Black Krim) have peel redder than the pulp due to greater accumulation of lycopene in the epicarp [8]. 
TABLE 2: Biometrics of tomato fruits, of different genotypes: fresh weight (FW), longitudinal diameter (LD), transverse diameter (TD), longitudinal and transverse diameter ratio (LD/TD), firmness (FIR), mesocarp thickness (THICK), number of locules (LOC), and seed quantity (SEM).

\begin{tabular}{|c|c|c|c|c|c|c|c|c|}
\hline Genotypes & $\begin{array}{c}\text { FW } \\
\mathrm{g}\end{array}$ & $\begin{array}{c}\mathrm{LD} \\
\mathrm{mm}\end{array}$ & $\begin{array}{l}\mathrm{TD} \\
\mathrm{mm}\end{array}$ & $\begin{array}{c}\mathrm{LD} / \mathrm{TD} \\
-\end{array}$ & $\begin{array}{l}\text { FIR } \\
\operatorname{kgf}\end{array}$ & $\begin{array}{c}\text { THICK } \\
\mathrm{mm}\end{array}$ & $\begin{array}{l}\text { LOC } \\
\text { Fruit }\end{array}$ & $\begin{array}{l}\text { SEM } \\
\text { Fruit }\end{array}$ \\
\hline Ellus & 95.62 & 54.52 & 62.23 & 1.01 & 2.79 & 6.19 & 2.87 & 83.12 \\
\hline Black Mauri & 17.50 & 28.54 & 38.03 & 0.75 & 2.06 & 2.85 & 2.17 & 50.69 \\
\hline Green Zebra & 52.50 & 47.16 & 43.53 & 1.07 & 1.71 & 3.25 & 2.96 & 40.33 \\
\hline Green Tomato & 59.79 & 50.62 & 40.18 & 1.25 & 1.89 & 3.79 & 4.92 & 95.56 \\
\hline Pitanga & 78.33 & 57.53 & 53.66 & 1.06 & 1.86 & 4.69 & 5.67 & 24.47 \\
\hline Black Krim & 68.96 & 52.58 & 51.86 & 1.02 & 1.94 & 4.41 & 4.52 & 29.13 \\
\hline Pomodoro Fiorentino & 72.14 & 63.76 & 38.34 & 1.67 & 1.39 & 3.82 & 6.90 & 58.47 \\
\hline Pomodoro Marmande & 92.08 & 63.14 & 44.99 & 1.40 & 1.82 & 4.25 & 7.62 & 99.81 \\
\hline $\mathrm{CV}(\%)$ & 15.82 & 7.22 & 5.34 & 27.12 & 28.73 & 22.43 & 37.40 & 23.89 \\
\hline
\end{tabular}

$\mathrm{CV}$ : coefficient of variation.

TABLE 3: Epicarp, mesocarp, and endocarp color of fruits from eight tomato genotypes.

\begin{tabular}{lcc}
\hline Genotypes & \multicolumn{2}{c}{ Color } \\
Ellus & Epicarp & Mesocarp and endocarp \\
Black Mauri & $\begin{array}{c}\text { Rosy red } \\
\text { Brownish red } \\
\text { Yellow with } \\
\text { green stripes }\end{array}$ & Brownish red \\
Green Zebra & Green \\
Pitanga & Cherry red & Green \\
Black Krim & Intense red & Rosy red \\
Pomodoro Fiorentino & Red & Red \\
Pomodoro Marmande & Rosy red & Rosy red \\
\hline
\end{tabular}

Lycopene is the most abundant carotene in red tomato fruits [14]. The biosynthesis is associated with the change in fruit color from green to red when chloroplasts are transformed to chromoplasts [15]. Its abundance is associated with genetic control (especially by increasing the expression of hp, $\mathrm{og}^{\mathrm{c}}$, and CrtL genes) $[8,16,17]$, fruit development time [18], water supply [19], and climatic conditions [8]. In addition, lycopene biosynthesis can be inhibited if high temperatures (above $30^{\circ} \mathrm{C}$ ) occur in fruits, often due to a high incidence of solar radiation in the epicarp [8].

The genotypes Green Zebra and Green Tomato stood out from the others due to the yellowish and greenish epicarp, respectively, and the green pulp (Table 3). The pigments present in genotypes Green Zebra and Green Tomato are possibly xanthophylls (lutein and zeaxanthin), oxygenated derivatives of carotenoids. Xanthophylls are powerful antioxidants associated with a reduction in the risk of eye diseases (e.g., age-related macular degeneration and cataract) $[20,21]$. In addition, high concentrations of lutein, zeaxanthin, and vitamin $C$ in the plasma could reduce the incidence of chronic diseases (cancer, diabetes, cardiovascular disease, and stroke) by preventing leukocyte telomere shortening [22].
Several enzymatic complexes, especially the lycopene cyclase, mediate carotenogenesis, in tomato fruits [16, 17]. Wild species holding green (S. neorickii, S. peruvianum, and $S$. pennellii) and yellow fruit (S. cheesmaniae) have polymorphisms in the coding region of the gene that encodes the enzyme $\beta$ lycopene cyclase [23]. Therefore, the inability of Green Zebra and Green Tomato fruits to accumulate lycopene is probably related with the mutation of genes associated with the lycopene cyclase.

3.1. Multivariate Analysis. The first and second components of the multivariate analysis of plant traits explained $73.38 \%$ of the total variance (Figure 1). The genotype Black Krim was represented in the first quadrant, Black Mauri in the second quadrant, and Ellus in the fourth quadrant. Such representation indicated that the traits number of fruits per plant at 80 DAT (Black Mauri), number of flowers per plant at 35 DAT (Black Krim), plant height at 35 DAT, and estimated production per plant and per hectare (Ellus) prevail in describing these genotypes. The genotypes Pomodoro Marmande, Pomodoro Fiorentino, Pitanga, and Green Zebra were located in the third quadrant and were characterized by having a low number of fruits per plant at both 35 DAT and 80 DAT.

The production of fruits per plant/area was positively correlated with plant height at 35 DAT. According to Piotto and Peres [24], the tomato plant only flourishes after issuing eight to twelve leaves. Therefore, genotypes that are more precocious with respect to vegetative growth may be more susceptible to hormonal and environmental stimuli, which favor flowering. Finally, this early vegetative maturity may provide greater accumulation of photoassimilates due to the increased competitiveness in capturing light, leading to a greater success in fruiting.

The first and second components of the multivariate analysis conducted for the fruit traits (Figure 2) explained $84.13 \%$ of the total variance. The occurrence of genotype Ellus in the second quadrant shows its prominence in regard to mesocarp thickness, fresh weight, and transverse diameter and confirms the importance of these traits in describing the 


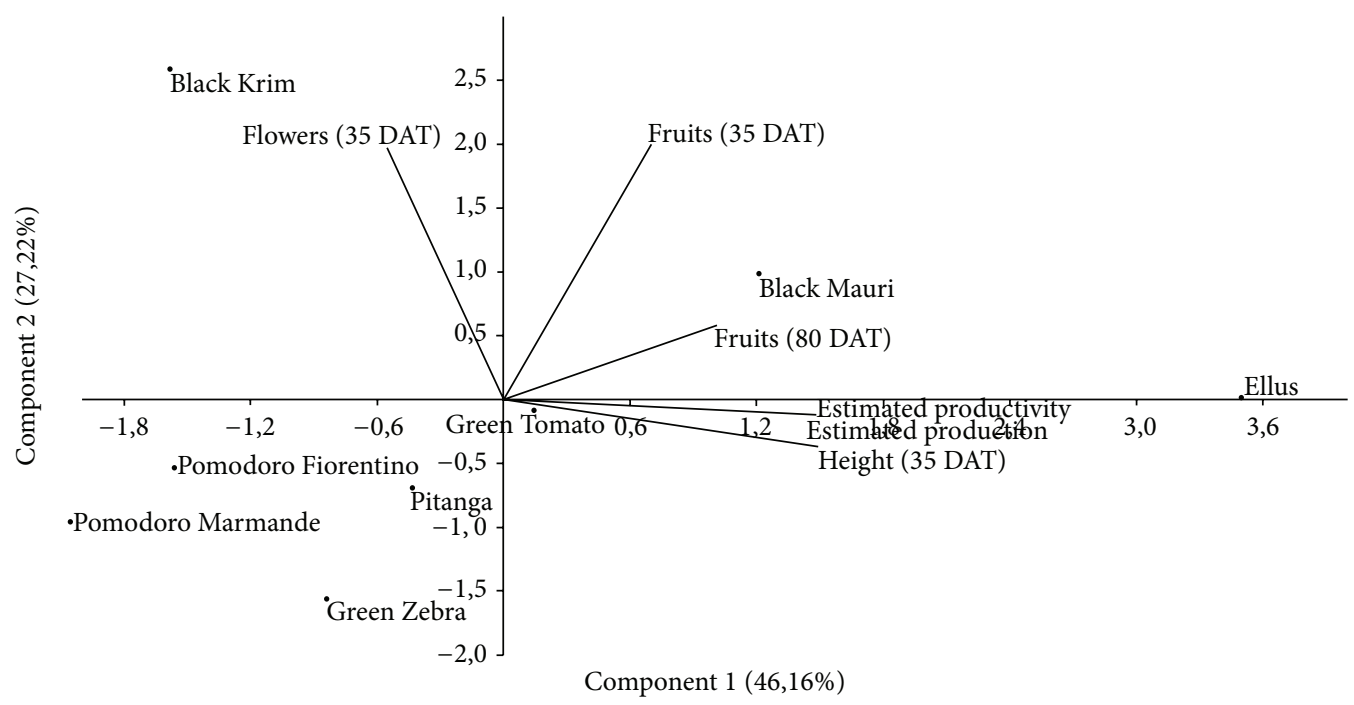

FIGURE 1: Biplot of plant variables (height, flowers, number of fruits, and production) and tomato genotypes relative to principal components 1 and 2.

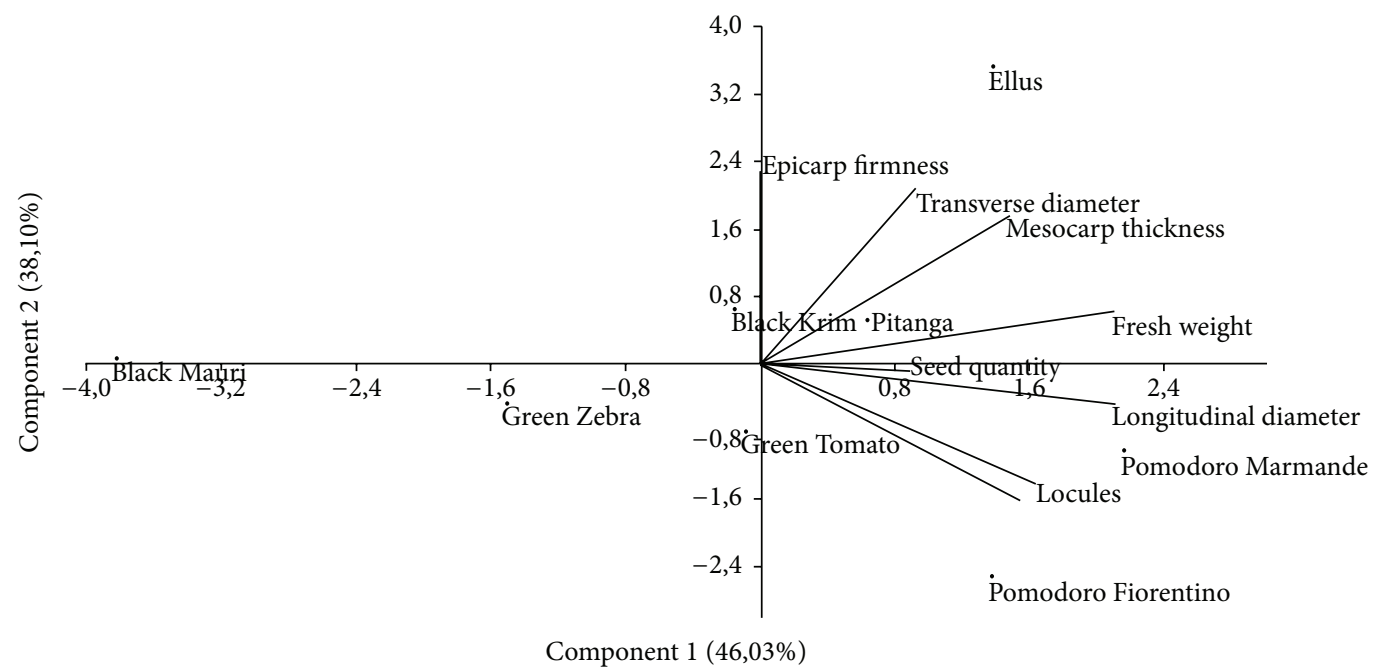

FIGURE 2: Biplot of fruit variables (fresh weight, longitudinal and transverse diameter, longitudinal and transverse diameter ratio, epicarp firmness, mesocarp thickness, locules, and number seeds) and tomato genotypes relative to principal components 1 and 2.

genotype Ellus. Meanwhile, low firmness of the epicarp was the best descriptor of fruit of the genotype Green Tomato.

The Italian genotypes Pomodoro Marmande and Fiorentino, located in the fourth quadrant, stood out from the others, especially by having a high number of locules and longitudinal/transverse diameter ratio. The locules are cavities within the fruit, derived from the ovary, where seed are submerged in placental mucilage. The number of locules is positively correlated with the number of seeds and fruit size in the fourth quadrant (Figure 2).

The genotype Black Mauri, represented in the first quadrant, differed mainly by the low mass and fruit size (Figure 2) and had twice the number of fruits as genotype Ellus (Table 1). Still, due to the low average mass of genotype Black Mauri (Table 2), production per plant and per area was approximately three times lower than for genotype Ellus.
Genotypes Black Krim and Pitanga had low numbers of seed per fruit.

Genotypes of specific growth, as Black Krim, are suitable for the production of fruits for industrial use. The combination of small size (Table 1), intense red peel (Table 3), and uniform maturation leads to an optimization of the mechanical harvesting and the processing of sauces and ketchups [8, 24].

Cluster analysis of plant traits enabled grouping the eight genotypes in only two groups (Figure 3). Group 1 comprised genotypes Green Tomato, Pitanga, Ellus, and Black Mauri and Group 2 genotypes Green Zebra, Pomodoro Fiorentino, Pomodoro Marmande, and Black Krim. The cluster of fruit traits (Figure 4) also indicated the existence of two groups: Group 1 (Green Tomato, Pomodoro Marmande, and Ellus) and Group 2 (Green Zebra, Pitanga, Black Krim, Pomodoro 


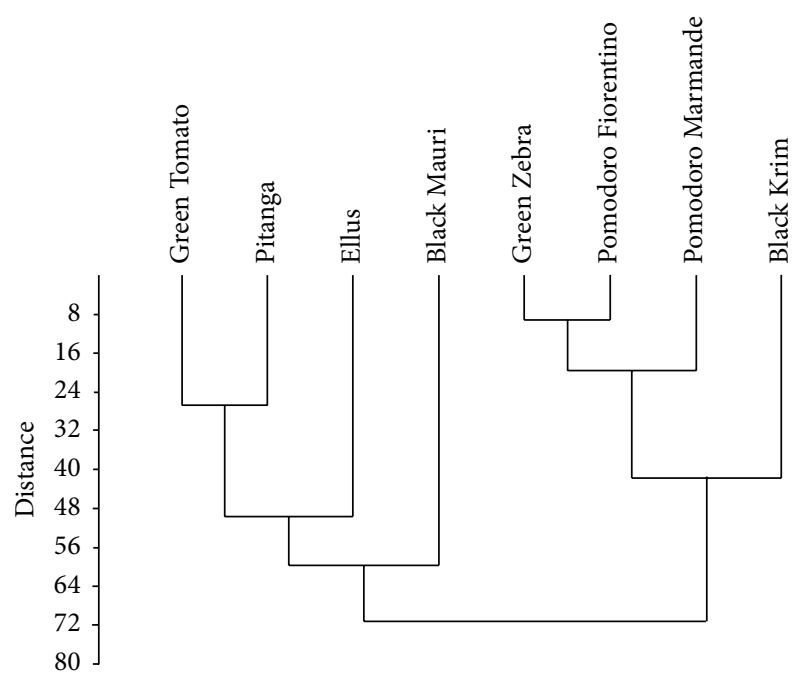

FIGURE 3: Similarity dendrogram of tomato genotypes associated with plant characteristics (height, flowers, fruits, and production).

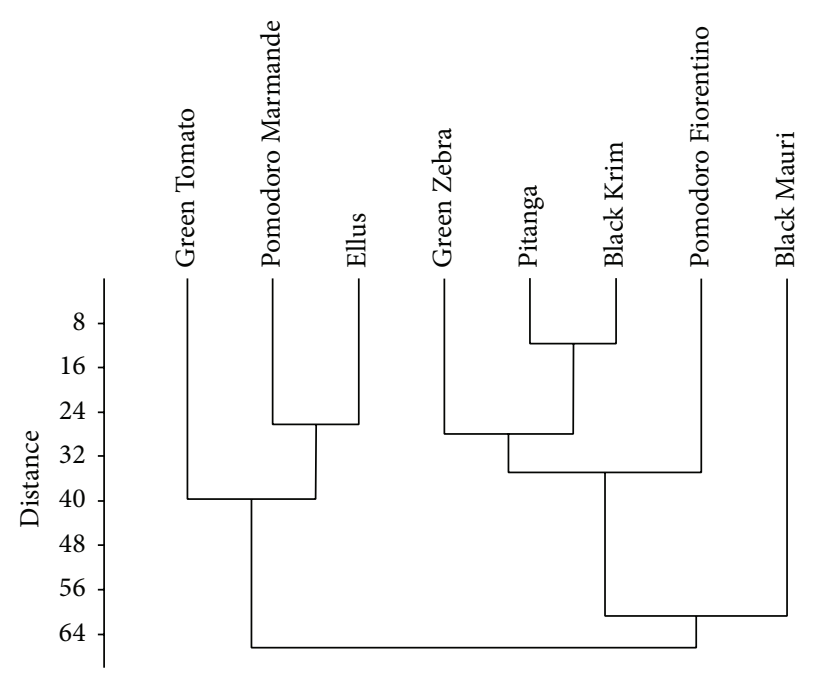

FIGURE 4: Similarity dendrogram of tomato genotypes associated with fruit characteristics (fresh mass weight, longitudinal and transverse diameter, relationship between longitudinal and transverse diameter, epicarp firmness, loci, and number of seeds).

Fiorentino, and Black Mauri). The intersection of the group pairs indicates a high level of similarity between genotypes Green Tomato and Ellus and genotypes Green Zebra, Pomodoro Fiorentino, and Black Krim.

\section{Conclusion}

The cluster and principal component analyses were efficient in characterizing plants and/or fruits of different tomato genotypes. Such efficiency enhances result interpretation and proposed inferences, with applied relevance for the producers.
The genotype Ellus has a combination of morphoagronomic plant and fruit traits superior to other genotypes. Such superior traits enable a high productivity.

\section{Conflict of Interests}

The authors declare that there is no conflict of interests regarding the publication of this paper.

\section{References}

[1] D. O. Ibitoye, P. E. Akin-Idowu, and O. T. Ademoyegun, "Agronomic and lycopene evaluation in tomato (Lycopersicon lycopersicum Mill.) as a function of genotype," World Journal of Agricultural Sciences, vol. 5, pp. 892-895, 2009.

[2] R. Ilahy, C. Hdider, M. S. Lenucci, I. Tlili, and G. Dalessandro, "Antioxidant activity and bioactive compound changes during fruit ripening of high-lycopene tomato cultivars," Journal of Food Composition and Analysis, vol. 24, no. 4-5, pp. 588-595, 2011.

[3] A. Raiola, M. M. Rigano, R. Calafiore, L. Frusciante, and A. Barone, "Enhancing the health-promoting effects of tomato fruit for biofortified food," Mediators of Inflammation, vol. 2014, Article ID 139873, 16 pages, 2014.

[4] P. M. Kris-Etherton, K. D. Hecker, A. Bonanome et al., "Bioactive compounds in foods: their role in the prevention of cardiovascular disease and cancer," The American Journal of Medicine, vol. 113, no. 9, supplement 2, pp. 71S-88S, 2002.

[5] M. Giovannetti, L. Avio, R. Barale et al., "Nutraceutical value and safety of tomato fruits produced by mycorrhizal plants," British Journal of Nutrition, vol. 107, no. 2, pp. 242-251, 2012.

[6] K. Zu, L. Mucci, B. A. Rosner et al., "Dietary lycopene, angiogenesis, and prostate cancer: a prospective study in the prostate-specific antigen era," Journal of the National Cancer Institute, vol. 106, no. 2, article djt430, 2014.

[7] Y. Li, V. L. W. Go, and F. H. Sarkar, "The role of nutraceuticals in pancreatic cancer prevention and therapy: targeting cellular signaling, MicroRNAs, and Epigenome," Pancreas, vol. 44, no. 1, pp. 1-10, 2015.

[8] S. Brandt, Z. Pék, É. Barna, A. Lugasi, and L. Helyes, "Lycopene content and colour of ripening tomatoes as affected by environmental conditions," Journal of the Science of Food and Agriculture, vol. 86, no. 4, pp. 568-572, 2006.

[9] Y. Bai and P. Lindhout, "Domestication and breeding of tomatoes: what have we gained and what can we gain in the future?" Annals of Botany, vol. 100, no. 5, pp. 1085-1094, 2007.

[10] J. M. Moita Neto and G. C. Moita, "Uma introdução à análise exploratória de dados multivariados," Química Nova, vol. 21, no. 4, pp. 467-469, 1998.

[11] J. F. Hair Junior, R. E. Anderson, R. L. Tatham et al., Análise multivariada de dados, Artmed, Porto Alegre, Brazil, 2005.

[12] M. T. A. Gusmão, S. A. L. Gusmão, and J. A. C. Araújo, "Produtividade de tomate tipo cereja cultivado em ambiente protegido e em diferentes substratos," Horticultura Brasileira, vol. 24, no. 4, pp. 431-436, 2006.

[13] Z. Pék and L. Helyes, "The effect of daily temperature on truss flowering rate of tomato," Journal of the Science of Food and Agriculture, vol. 84, no. 13, pp. 1671-1674, 2004.

[14] N. Lavi, Y. Tadmor, A. Meir et al., "Characterization of the intense pigment tomato genotype emphasizing targeted fruit 
metabolites and chloroplast biogenesis," Journal of Agricultural and Food Chemistry, vol. 57, no. 11, pp. 4818-4826, 2009.

[15] Z. Pék, L. Helyes, and A. Lugasi, "Color changes and antioxidant content of vine and postharvest ripened tomato fruits," HortScience, vol. 45, no. 3, pp. 466-468, 2010.

[16] I. Pecker, R. Gabbay, F. X. Cunningham Jr., and J. Hirschberg, "Cloning and characterization of the cDNA for lycopene $\beta$ cyclase from tomato reveals decrease in its expression during fruit ripening," Plant Molecular Biology, vol. 30, no. 4, pp. 807819, 1996.

[17] G. Ronen, M. Cohen, D. Zamir, and J. Hirschberg, "Regulation of carotenoid biosynthesis during tomato fruit development: expression of the gene for lycopene epsilon-cyclase is downregulated during ripening and is elevated in the mutant Delta," The Plant Journal, vol. 17, no. 4, pp. 341-351, 1999.

[18] D. Znidarcic and T. Pozrl, "Comparative study of quality changes in tomato cv. 'Malike' (Lycopersicon esculentum Mill.) whilst stored at different temperatures," Acta Agriculture Slovenica, vol. 87, no. 2, pp. 235-243, 2006.

[19] L. Helyes, A. Lugasi, and Z. Pék, "Effect of irrigation on processing tomato yield and antioxidant components," Turkish Journal of Agriculture and Forestry, vol. 36, no. 6, pp. 702-709, 2012.

[20] J. L. Olea, J. A. Aragón, M. E. Zapata, and J. Tur, "Características de la población con ingesta baja en luteína y zeaxantina en pacientes con degeneración macular asociada a la edad variante húmeda," Archivos de la Sociedad Española de Oftalmología, vol. 87, no. 4, pp. 112-118, 2012.

[21] J. Karppi, J. A. Laukkanen, and S. Kurl, "Plasma lutein and zeaxanthin and the risk of age-related nuclear cataract among the elderly Finnish population," British Journal of Nutrition, vol. 108, no. 1, pp. 148-154, 2012.

[22] A. Sen, G. Marsche, P. Freudenberger et al., "Association between higher plasma lutein, zeaxanthin, and vitamin C concentrations and longer telomere length: results of the Austrian Stroke Prevention Study," Journal of the American Geriatrics Society, vol. 62, no. 2, pp. 222-229, 2014.

[23] A. H. Araújo, M. E. D. N. Fonseca, and L. S. Boiteux, "Nucleotide diversity of a major carotenoid biosynthetic pathway gene in wild and cultivated Solanum (Section lycopersicon) species," Brazilian Journal of Plant Physiology, vol. 19, no. 3, pp. 233-237, 2007.

[24] F. A. Piotto and L. E. P. Peres, "Base genética do hábito de crescimento e florescimento em tomateiro e sua importância na agricultura," Ciência Rural, vol. 42, no. 11, pp. 1941-1946, 2012. 


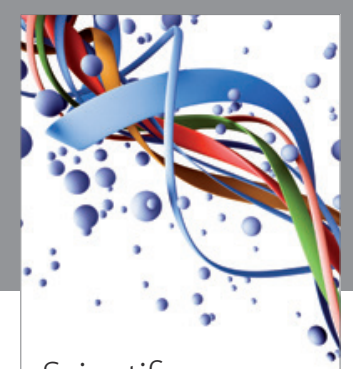

Scientifica
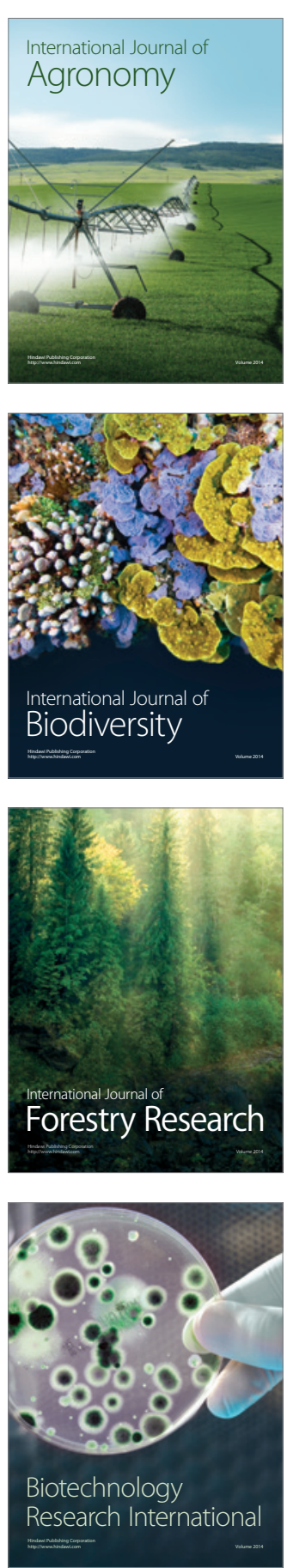
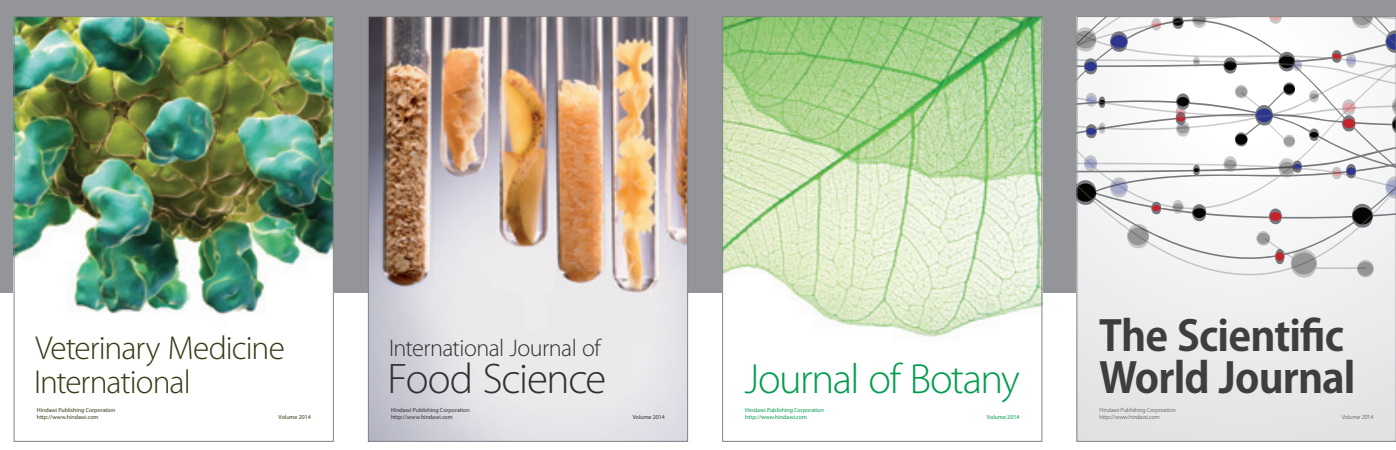

The Scientific World Journal
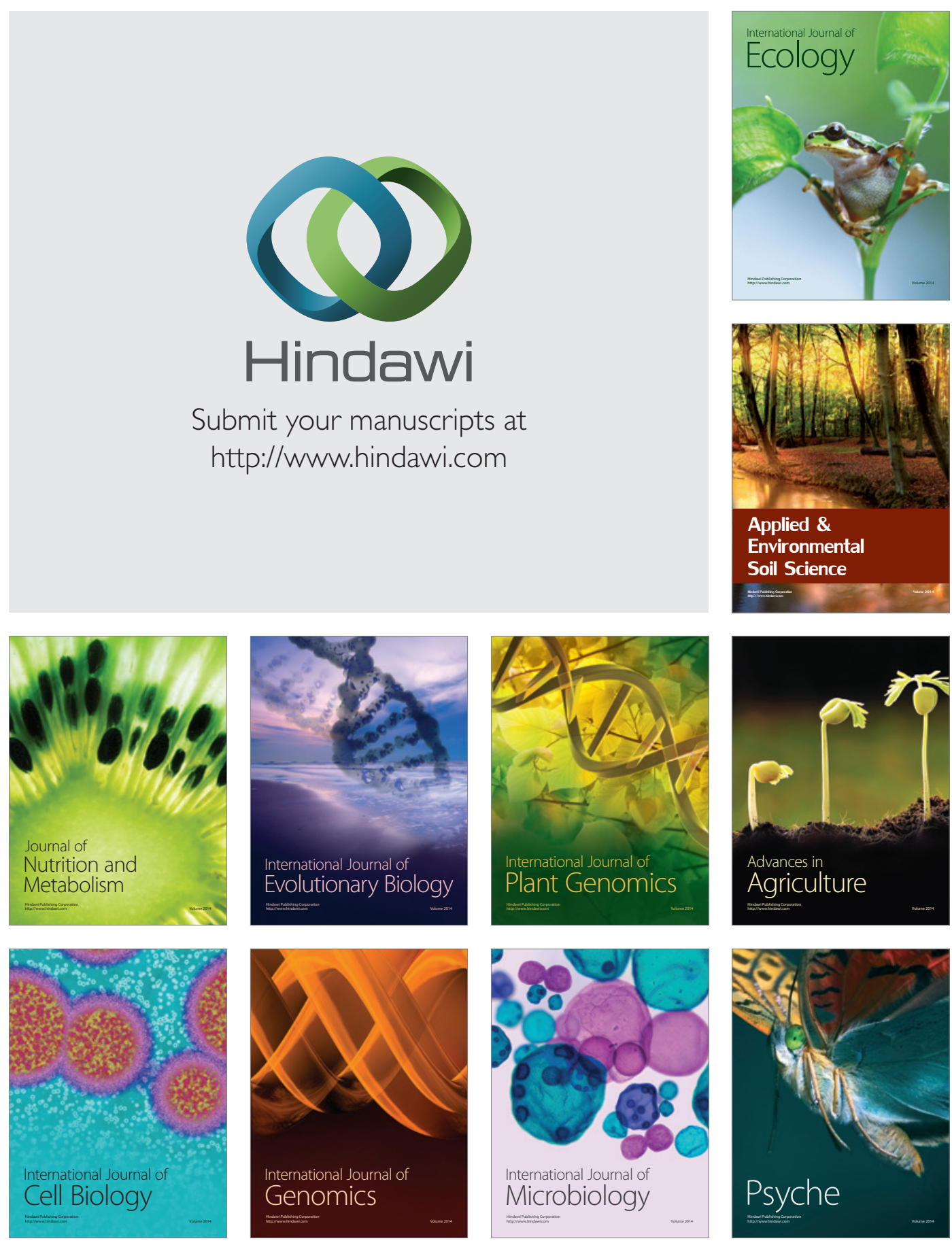